\title{
TINGKAT KETERAMPILAN DAN PENGETAHUAN NELAYAN DI KARANGANTU BANTEN
}

\author{
Skillfulness and Knowledge Fishermen Level in Karangantu, Banten
}

\author{
Oleh: \\ Mahdi Amin ${ }^{1 *}$, Fis Purwangka ${ }^{2}$, Wazir Mawardi ${ }^{2}$ \\ ${ }^{1}$ Mahasiswa Program Sarjana Departemen Pemanfaatan Sumberdaya Perikanan, FPIK, \\ Institut Pertanian Bogor \\ ${ }^{2}$ Staf Pengajar Departemen Pemanfaatan Sumberdaya Perikanan, FPIK, Institut Pertanian \\ Bogor \\ *Korespondensi: mahdiamin84@gmail.com
}

\begin{abstract}
ABSTRAK
Nelayan merupakan salah satu profesi yang sangat dibutuhkan dalam pemanfaatan potensi sumber daya ikan. Profesi tersebut memiliki karakteristik pekerjaan yang bersifat "3d' yaitu membahayakan (dangerous), kotor (dirty), dan sulit (difficult). Maka dari itu dibutuhkan keterampilan dan pengetahuan yang memadai dalam profesi tersebut. Masalah keterampilan dan pengetahuan nelayan untuk saat ini tidak hanya menjadi perhatian pemerintah Indonesia saja, melainkan sudah menjadi perhatian dunia. Kebijakan-kebijakan yang dikeluarkan, secara jelas telah mengatur tentang pendidikan dan pelatihan untuk pelaut kapal penangkap ikan, namun pengimplementasiaanya masih kurang. Data yang dikumpulkan ada dua jenis, data primer diperoleh dengan cara wawancara mendalam melalui kuesioner, sedangkan data sekunder diperoleh dengan cara melakukan penelusuran dokumen terkait informasi mengenai tingkat keterampilan dan pengetahuan nelayan kepada instansi yang berwenang. Pengambilan data dilakukan dengan menggunakan metode purposive sampling terhadap beberapa pihak yang terkait dengan peningkatan keterampilan dan pengetahuan nelayan. Tujuan dari penelitian ini untuk mengidentifikasi kompetensi yang seharusnya dimiliki oleh nelayan, serta mengevaluasi kompetensi nelayan di PPN Karangantu, Banten sesuai dengan kompetensi yang seharusnya dimiliki nelayan. Hasil penelitian ini menunjukkan bahwa kompetensi nelayan di PPN Karangantu, dapat dibilang masih cukup rendah, karena hampir $80 \%$ nelayan kurang memahami tentang kompetensi apa saja yang seharusnya dimiliki. Selain itu juga, kompetensi nelayan di PPN Karangantu, masih belum sesuai dengan standar kompetensi kerja yang telah ditetapkan.
\end{abstract}

Kata kunci: keterampilan dan pengetahuan, nelayan, PPN Karangantu.

\begin{abstract}
Fisherman is one of the profession that was really needed for utilization of fisheries resources. That profession has work characteristics called "3d" that are dangerous, dirty and difficult. Therefore, insufficient skillfulness and knowledge was needed in this profession. The problem of fisherman skillfulness and knowledge for this moment not only become the Indonesian government concern, but had become worldwide attention. Policy that has been settled, clearly have regulated about education and training for fisherman catching fish ship, but still lack in the implementation. Data that was collected contained of two type, that are primary data and secondary data. Primary data obtained by circumstantial interview through questionnaire, while secondary data obtained by conducting research for documents related with information about fisherman skillfulness and knowledge level to the authorized agency. The collection of data was done by using the method of
\end{abstract}


sampling to purposive toward several parties that related with improving fisherman skillfulness and knowledge. The purpose of this research was to identify which competence supposed to be possessed by fisherman, and also to evaluate fishermen competence in the PPN Karangantu, Banten in accordance with competence that should have by fisherman. This research result indicates that fisherman competence in the PPN Karangantu, literally was still quite low, because almost 80\% fishermen less understanding about whatever competence should they have. It is also, fisherman competence in the PPN Karangantu, still not appropriate with standard of work competency that has been set.

Keywords: skills and knowledge, fisherman, PPN Karangantu.

\section{PENDAHULUAN}

Nelayan merupakan salah satu profesi yang sangat dibutuhkan dalam pemanfaatan potensi sumberdaya ikan. Profesi tersebut memiliki karakteristik pekerjaan yang bersifat "3d" yaitu: membahayakan (dangerous), kotor (dirty), dan sulit (difficult). Akibat dari sifat-sifat pekerjaan sebagai pelaut kapal penangkap ikan, kebanyakan orang kurang tertarik terhadap profesi tersebut, mereka cenderung untuk memilih pekerjaan di bidang lainnya, seperti: teknologi informasi, hukum, ekonomi, bisnis yang lebih populer. Hal tersebut biasanya terjadi pada di negara maju seperti di Jepang, Korea, dan negara maju lainnya.Negara-negara maju di bidang penangkapan ikan, umumnya mendatangkan tenaga kerja pelaut kapal penangkap ikan dari Negara berkembang seperti Indonesia, China, Vietnam, dan Philipina (FAO, 2000).

Dewasa ini, nelayan dituntut untuk mampu berkompetisi secara global. Hal ini dapat dibuktikan dengan dimilikinya sertifikat kompetensi kepelautan standar internasional, seperti Sertifikat Ahli Nautika Kapal Penangkap Ikan (ANKAPIN) Tingkat I, II dan III (Certificate of Competency for Deck Officer of Fishing Vessel Level I, II, III) untuk bagian dek dan Sertifikat Ahli Teknika Kapal Penangkap Ikan (ATKAPIN) Tingkat I, II dan III untuk bagian mesin (Certificate of Competency for Engine Officer of Fishing Vessel). Khususnya di Indonesia terdapat kurang lebih 2,78 juta orang yang berprofesi sebagai nelayan, namun pada umumnya nelayan tersebut belum memiliki sertifikat kompetensi (Certificate of Competency) kepelautan perikanan maupun sertifikat keterampilan (Certificate of Proficiency) yang sebagai mana disyaratkan. Sedangkan untuk mendapatkan sertifikat tersebut diperlukan pendidikan atau pelatihan kepelautan kapal penangkap ikan pada lembaga pendidikan atau lembaga pelatihan yang telah memenuhi standar nasional maupun internasional.

Berdasarkan Direktorat Jenderal Perhubungan Laut, dalam Unus 2004 menyatakan besarnya persentase penyebab terjadinya kecelakaan kapal di Indonesia, yang termasuk di dalamnya kapal ikan menurut faktor penyebab yaitu 43,67\% disebabkan oleh kesalahan manusia (human error), $32,37 \%$ disebabkan oleh faktor alam dan $23,94 \%$ oleh faktor teknis. Sedangkan menurut IMO (International Maritime Organization) kecelakaan kapal ikan menurut faktor kesalahan manusia, faktor alam, dan faktor teknis masing-masing sebesar 43,06\%, 33,57\% dan 23,35\%.

Banyak terjadi kecelakaan kapal disebabkan oleh kesalahan manusia dan kesalahan ini sebagai hasil dari kurangnya kualitas manajemen. Permasalahan yang sering dihadapi oleh nelayan, khususnya nelayan Indonesia adalah minimnya pengetahuan (knowledge), dan keterampilan (skill). Hal tersebut dapat berimbas pada ketidakmampuan nelayan dalam mengakses tekhnologi, informasi, dan kurangnya penguasaan kompetensi keselamatan dan kompetensi penangkapan serta kemampuan dalam penanganan hasil tangkapan ikan. Disisi lain, rendahnya tingkat pendidikan dan keterampilan nelayan dapat mengakibatkan rendahnya kesadaran terhadap pentingnya menjaga kelestarian lingkungan sehingga sering terjadi kasus-kasus penangkapan ikan yang tidak bertanggung jawab 
misalnya menggunakan bahan peledak, bahan kimia, listrik atau jenis alat tangkap illegal, yang berakibat kepada rendahnya tingkat keselamatan penangkapan.

Pada kondisi seperti ini, peranan pemerintah sangat dibutuhkan untuk meminimalisir permasalahan yang ada. Berdasarkan pasal 57 yang terdapat pada UU No. 31 tahun 2004 dan UU No. 45 tahun 2009 tentang perikanan yang membahas tentang pendidikan, penyuluhan, dan pelatihan yang diselenggarakan oleh pemerintah guna untuk meningkatkan dan menghasilkan sumberdaya manusia (SDM) yang berkualitas perlu dilakukan. Selain itu juga pendataan tentang tingkat pendidikan yang dimiliki oleh nelayan perlu dilakukan agar pemerintah dapat dengan mudah menentukan kebijakan untuk meningkatkan dan menghasilkan sumberdaya manusia (SDM) yang berkualitas.

Hamzens dan Sumardjo (2007) menyebutkan bahwa mutu sumber daya manusia nelayan adalah rendah, dicirikan dengan kompetensi rendah seperti kesadaran akan keselamatan saat melaut rendah, kemampuan merencanakan usaha rendah, kemampuan menangkap ikan rendah, dan kemampuan memecahkan masalah usaha rendah. Menurut Retnowati (2014) menyatakan bahwa akar penyebab masalah yang terkait dengan SDM nelayan adalah masalah pendidikan. Selain itu juga masalah kompetensi yang terkandung unsur keterampilan, pengetahuan, dan kemampuan semua ini mereka dapatkan dari proses pembelajaran yang bersifat turun temurun, sehingga kompetensi ini masih dapat ditingkatkan untuk menjadi lebih baik. Oleh karena itu diperlukan standar kompetensi nelayan yang dapat meningkatkan kualitas nelayan terutama dalam kesadaran akan keselamatan saat melaut. Tujuan dari penelitian ini adalah untuk mengidentifikasi kompetensi yang seharusnya dimiliki oleh nelayan, dan mengevaluasi kompetensi nelayan di PPN Karangantu Banten sesuai dengan kompetensi yang seharusnya dimiliki nelayan.

\section{METODE PENELITIAN}

Penelitian ini dilaksanakan pada bulan September 2014 bertempat di Kecamatan Kasemen Kota Serang, Banten. Penelitian lapang ini dilakukan selama bulan September 2014. Metode penelitian ini menggunakan metode purposive sampling. Data yang dikumpulkan terdiri atas data primer dan data sekunder. Data primer dikumpulkan dengan cara melakukan proses wawancara secara mendalam terhadap 50 orang nelayan di PPN Karangantu, Banten terkait degan kompetensi yang dimiliki oleh nelayan itu sendiri. Sedangkan data sekunder dikumpulkan dengan cara melakukan penelusuran dokumen mengenai informasi tingkat pengetahuan dan keterampilan nelayan terhadap instansi terkait dengan kurikulum atau materi keterampilan dan pengetahuan untuk nelayan, diantaranya dinas perikanan, dinas pendidikan, dan lembaga formal maupun informal yang berada di lokasi tersebut.

Data yang dikumpulkan kemudian dianalisis untuk mendapatkan suatu kesimpulan. Adapun bentuk teknik analisis data adalah dengan Analisis Deskriptif Komparatif dan Content Analysis atau Analisis Isi. Metode analisis deskriptif komparatif merupakan suatu metode yang digunakan dalam mengumpulkan, menyusun, menggunakan, serta menafsirkan data yang sudah ada. Selanjutnya, data tersebut akan diuraikan secara lengkap, teratur, dan teliti terhadap suatu obyek penelitian yang kemudian akan dibandingkan dengan data yang memiliki kesamaan terhadap suatu obyek penelitian. Analisis deskriptif komparatif yakni data yang dikumpulkan adalah berupa tingkat pendidikan serta keterampilan yang dimiliki oleh nelayan.Analisis pihak-pihak terkait dilakukan dengan mengevaluasi keberadaan dan peran yang dilakukan oleh instansi tersebut yang berkaitan dengaan pengetahuan dan keterampilan nelayan. Analisis yang digunakan dalam penelitian ini adalah metode analisis dimana data deskriptif sering hanya dianalisis menurut isinya. Oleh karena itu analisis semacam ini juga disebut analisis isi (Content Analysis) (Suryabrata 1983). Metode Content Analysis, dilakukan pengkajian secara mendalam mengenai isi atau materi yang terdapat pada dokumen (peraturan) mengenai peningkatan kualitas sumberdaya manusia khususnya nelayan. 


\section{HASIL DAN PEMBAHASAN}

\section{Kompetensi Nelayan Berdasarkan SKKNI (Standar Kompetensi Kerja Nasional Indonesia)}

Kompetensi merupakan kemampuan seseorang atau individu dalam melaksanakan atau melakukan suatu pekerjaan yang dilandasi oleh keterampilan dan pengetahuan yang dicirikan oleh profesionalisme dalam suatu bidang tertentu sebagai suatu yang terpenting. Kompetensi sendiri dapat dipengaruhi oleh beberapa faktor, antara lain keyakinan dan nilai-nilai, keterampilan, pengalaman, karakteristik kepribadian, motivasi, isu emosional, kemampuan intelektual, dan budaya organisasi (Wibowo, 2009).

Menurut Keputusan Menteri Tenaga Kerja dan Transmigrasi Republik Indonesia nomor 289 tahun 2003, Standar Kompetensi Kerja Nasional Indonesia (SKKNI) adalah rumusan kemampuan kerja yang mencakup aspek pengetahuan, keterampilan dan atau keahlian, serta sikap kerja yang relevan dengan pelaksanaan tugas dan syarat jabatan yang ditetapkan sesuai dengan ketentuan perundang-undangan. Rumusan SKKNI ini dapat menciptakan hubungan timbal balik antara dunia usaha dengan lembaga diklat, yaitu bagi suatu perusahaan atau industri yang harus dapat merumuskan standar kebutuhan kualifikasi SDM yang diinginkan, dalam upaya menjamin kesinambungan usaha atau industri. Selain itu juga SKKNI ini dapat dijadikan acuan dalam mengembangkan program dan kurikulum pendidikan dan pelatihan yang akan dilaksanakan oleh pihak lembaga diklat. Pihak pemerintah juga dapat menggunakan SKKNI sebagai acuan dalam merumuskan kebijakan dalam pengembangan SDM secara makro. Adapun salah satu tujuan utama dengan adanya SKKNI adalah untuk menghasilkan sumberdaya manusia khususnya di bidang penangkapan ikan yang berkompeten, sehingga sumberdaya manusia tersebut dapat bersaing secara global. Dalam menghasilkan sumberdaya manusia khususnya di bidang penangkapan ikan dapat dilakukan dengan cara melakukan standarisasi dan sertifikasi di sektor perikanan tangkap.

Berdasarkan Standar Kompetensi Kerja Nasional Indonesia (SKKNI) khususnya di bidang penangkapan ikan terdapat 5 komponen penting yang harus dikuasai oleh seseorang yang bekerja dalam bidang penangkapan ikan antara lain melakukan penangkapan ikan di laut, merancang bangun alat penangkap ikan, melakukan proses penangkapan ikan, merawat alat penangkap ikan, dan melakukan penanganan ikan hasil tangkapan. Dalam 5 komponen utama terkait kompetensi yang harus dimiliki oleh nelayan tersebut, terbagi dalam 23 unit jenis kompetensi yang ada didalamnya. Selain itu juga dari 23 unit jenis kompetensi tersebut memiliki batasan-batasan serta tujuan yang berbeda-beda dalam setiap jenis kompetensinya. Adapun penjelasan terkait 23 unit jenis kompetensi yang harus dikuasai oleh nelayan, dapat dilihat berikut ini:

1. Merencanakan operasi penangkapan ikan

2. Menyiapkan kelaiklautan kapal

3. Menyiapkan kelaiklautan operasi penangkapan ikan

4. Melaksanakan tugas jaga laut

5. Merakit pukat cincin

6. Merakit pukat hela

7. Merakit jaring insang

8. Merakit rawai tuna

9. Merakit huhate

10. Melakukan penangkapan ikan di laut menggunakan pukat cincin satu kapal

11. Melakukan penangkapan ikan di laut dengan menggunakan pukat hela

12. Mengoperasikan jaring insang hanyut (drift gillnet)

13. Melakukan penangkapan ikan di laut dengan menggunakan rawai tuna (tuna long-line)

14. Melakukan penangkapan ikan di laut dengan menggunakan huhate (pole \& line)

15. Melakukan perawatan alat penangkap ikan berbahan utama webbing

16. Melakukan perbaikan alat penangkap ikan berbahan utama webbing 
17. Melakukan perawatan alat penangkap ikan berbahan utama tali dan pancing di darat

18. Melakukan perawatan alat penangkap ikan berbahan utama tali dan pancing di kapal

19. Melakukan perbaikan alat penangkap ikan berbahan utama tali dan pancing

20. Melakukan penanganan ikan tuna di kapal

21. Melakukan penanganan ikan pelagis kecil di kapal

22. Melakukan penanganan ikan demersal di kapal

23. Melakukan penanganan udang di kapal

\section{Kompetensi Nelayan di PPN Karangantu, Banten}

Penduduk yang bermukim di sekitar PPN Karangantu, Banten sebagian besar berprofesi sebagai nelayan. Nelayan yang berada di lokasi tersebut didominasi oleh nelayan kecil, yang umumnya masih menggunakan teknologi penangkapan sederhana, peralatan penangkapan ikan dioperasikan secara manual dengan tenaga manusia, serta kemampuan berlayar terbatas hanya pada perairan pantai. Nelayan tersebut dibagi atas dua ketegori, yaitu nelayan buruh dan nelayan pemilik. Nelayan buruh merupakan nelayan yang bekerja dengan menggunakan alat tangkap orang lain. Sedangkan nelayan pemilik merupakan nelayan yang memiliki alat tangkap yang dioperasikan oleh orang lain (Subri 2005).

Alat tangkap yang banyak digunakan oleh nelayan setempat adalah berupa gillnet. Nelayan setempat biasanya melakukan operasi penangkapan ikan di daerah sekitar Teluk Banten, selain itu apabila stok sumberdaya ikan yang berada di sekitar Teluk Banten mulai berkurang, nelayan setempat mengalihkan daerah penangkapan ikan di sekitar Teluk Jakarta dan juga Selat Sunda. Kapal yang banyak digunakan oleh nelayan setempat, yaitu kapal motor dengan ukuran < 5 GT, dengan jumlah awak kapal sekitar empat orang. Awak kapal tersebut, memiliki tugasnya masing-masing antara lain nahkoda, kapten, serta ABK. Namun pembagian kerja tersebut tidak begitu nampak, karena pada saat operasi penangkapan hampir semuanya bekerja secara merata. Kesadaran nelayan mengenai keselamatan kerja belum menjadi fokus utama bagi nelayan itu sendiri. Nelayan cenderung berani mengambil resiko yang cukup besar pada saat melakukan operasi penangkapan, karena alasan ekonomi semata. Hal tersebut dikarenakan nelayan hanya mengandalkan pengetahuan yang minim serta kurangnya pemahaman mengenai keselamatan kerja. Maka dari itu untuk meningkatkan keselamatan kerja nelayan pada saat melaut diperlukan standar kompetensi kerja untuk nelayan.

Kompetensi yang dimiliki nelayan di PPN Karangantu, dapat dibilang masih cukup rendah. Hal tersebut dikarenakan hampir 64,27\% nelayan setempat masih kurang dalam memahami tentang standar kompetensi kerja yang dibutuhkan oleh nelayan. Selain itu juga nelayan yang berada di PPN Karangantu belum memiliki sertifikat kompetensi. Salah satu penyebab minimnya kompetensi yang dimiliki oleh nelayan dikarenakan tingkat pendidikan yang dimiliki oleh nelayan itu sendiri terbilang cukup rendah, sehingga berpengaruh terhadap tingkat pengetahuan dan keterampilan yang dimiliki oleh nelayan. Berdasarkan data dari BPS Kota Serang tahun 2013 tingkat pendidikan yang dimiliki oleh penduduk yang berada di sekitar wilayah Karangantu, Banten yaitu 4.839 orang tidak tamat sekolah, 12.871 orang tamat dari SD atau SMP, 2.280 orang tamat dari SMA/SMK, serta 775 orang tamat dari perguruan tinggi (PT). Pada Tabel 1 dapat dilihat terkait dengan pemahaman nelayan terhadap standar kompetensi yang seharusnya dimiliki oleh nelayan. 
Tabel 1 Pemenuhan nelayan terkait standar kompetensi

\begin{tabular}{|c|c|c|c|}
\hline No & Standar Kompetensi & $\begin{array}{c}\text { Pemenuhan Standar } \\
\text { Kompetensi oleh } \\
\text { Nelayan }\end{array}$ & $\begin{array}{c}\text { Persentase } \\
\text { (\%) }\end{array}$ \\
\hline 1 & $\begin{array}{l}\text { Merencanakan operasi penangkapan ikan. } \\
\text { Elemen kompetensi : } \\
\text { a. Menentukan jenis ikan sasaran, alat } \\
\text { penangkap ikan dan daerah penangkapan } \\
\text { ikan } \\
\text { b. Memprakirakan cuaca } \\
\text { c. Menghitung waktu dan kebutuhan operasi } \\
\text { d. Mendokumentasikan rencana pelayaran }\end{array}$ & $\begin{array}{l}\text { Merencanakan operasi } \\
\text { penangkapan ikan. } \\
\text { Elemen kompetensi : } \\
\text { a. Dipenuhi } \\
\text { b. - } \\
\text { c. Dipenuhi } \\
\text { d. - }\end{array}$ & $50 \%$ \\
\hline 2 & $\begin{array}{l}\text { Menyiapkan kelaiklautan kapal. Elemen } \\
\text { kompetensi : } \\
\text { a. Melengkapi dokumen kapal } \\
\text { b. Melengkapi jumlah awak kapal sesuai } \\
\text { kualifikasi dan fungsinya } \\
\text { c. Melengkapi perlengkapan keselamatan } \\
\text { kapal dan manusia } \\
\text { d. Melaporkan keberangkatan kapal ke } \\
\text { syahbandar perikanan dan syahbandar } \\
\text { umum }\end{array}$ & $\begin{array}{l}\text { Menyiapkan kelaiklautan } \\
\text { kapal. Elemen } \\
\text { kompetensi : } \\
\text { a. Dipenuhi } \\
\text { b. Dipenuhi } \\
\text { c. - } \\
\text { d. - }\end{array}$ & $50 \%$ \\
\hline 3 & $\begin{array}{l}\text { Menyiapkan kelaiklautan operasi penangkapan } \\
\text { ikan. Elemen kompetensi : } \\
\text { a. Melengkapi dokumen perijinan yang terkait } \\
\text { dengan usaha penangkapan ikan } \\
\text { b. Melengkapi kebutuhan perbekalan kapal } \\
\text { dan awak kapal } \\
\text { c. Menyiapkan alat dan perlengkapan } \\
\text { penangkap ikan }\end{array}$ & $\begin{array}{l}\text { Menyiapkan kelaiklautan } \\
\text { operasi penangkapan } \\
\text { ikan. Elemen kompetensi } \\
\text { : } \\
\text { a. - } \\
\text { b. - } \\
\text { c. Dipenuhi }\end{array}$ & $33,33 \%$ \\
\hline 4 & $\begin{array}{l}\text { Melaksanakan tugas jaga laut. Elemen } \\
\text { kompetensi : } \\
\text { a. Menyiapkan perlengkapan tugas jaga laut } \\
\text { b. Memantau rute, pengendalian kapal dan } \\
\quad \text { keamanan berlayar }\end{array}$ & $\begin{array}{l}\text { Melaksanakan tugas jaga } \\
\text { laut. Elemen kompetensi } \\
\text { : } \\
\text { a. - } \\
\text { b. Dipenuhi }\end{array}$ & $50 \%$ \\
\hline 5 & $\begin{array}{l}\text { Merakit alat tangkap pukat cincin. Elemen } \\
\text { kompetensi : } \\
\text { a. Menjabarkan desain alat tangkap } \\
\text { b. Menyiapkan kebutuhan peralatan dan } \\
\text { bahan } \\
\text { c. Merangkai komponen alat tangkap }\end{array}$ & $\begin{array}{l}\text { Merakit alat tangkap } \\
\text { pukat cincin. Elemen } \\
\text { kompetensi : } \\
\text { a. - } \\
\text { b. - } \\
\text { c. - }\end{array}$ & $0 \%$ \\
\hline
\end{tabular}




\begin{tabular}{|c|c|c|c|}
\hline No & Standar Kompetensi & $\begin{array}{c}\text { Pemenuhan Standar } \\
\text { Kompetensi oleh } \\
\text { Nelayan }\end{array}$ & $\begin{array}{l}\text { Persentase } \\
\text { (\%) }\end{array}$ \\
\hline 6 & $\begin{array}{l}\text { Melakukan penangkapan ikan di laut } \\
\text { menggunakan pukat cincin satu kapal. Elemen } \\
\text { kompetensi : } \\
\text { a. Memantau keberadaan dan pergerakan } \\
\text { ikan, arah dan kekuatan angin, arah dan } \\
\text { kekuatan arus } \\
\text { b. Melakukan persiapan alat dan perlengkapan } \\
\text { penangkapan ikan dengan pukat cincin } \\
\text { c. Melingkari gerombolan ikan (setting) } \\
\text { d. Mengerutkan tali kerut (pursing) } \\
\text { e. Menaikan jaring ke kapal (hauling) } \\
\text { f. Menaikan ikan ke kapal (brailing) } \\
\text { g. Menyiapkan alat dan perlengkapan untuk } \\
\text { operasi berikutnya }\end{array}$ & $\begin{array}{l}\text { Melakukan penangkapan } \\
\text { ikan di laut } \\
\text { menggunakan pukat } \\
\text { cincin satu kapal. Elemen } \\
\text { kompetensi : } \\
\text { a. - } \\
\text { b. - } \\
\text { c. - } \\
\text { d. - } \\
\text { e. - } \\
\text { f. - } \\
\text { g. - }\end{array}$ & $0 \%$ \\
\hline 7 & $\begin{array}{l}\text { Melakukan penangkapan ikan di laut dengan } \\
\text { menggunakan pukat hela. Elemen kompetensi : } \\
\text { a. Menentukan daerah penangkapan ikan } \\
\text { b. Melakukan persiapan alat dan perlengkapan } \\
\text { penangkapan ikan dengan pukat hela } \\
\text { c. Menurunkan pukat hela untuk dioperasikan } \\
\text { (setting) di perairan } \\
\text { d. Menghela pukat (towing) } \\
\text { e. Menaikan pukat hela ke atas kapal (hauling) } \\
\text { f. Menyiapkan alat dan perlengkapan untuk } \\
\text { operasi berikutnya }\end{array}$ & $\begin{array}{l}\text { Melakukan penangkapan } \\
\text { ikan di laut dengan } \\
\text { menggunakan pukat } \\
\text { hela. Elemen kompetensi } \\
: \\
\text { a. - } \\
\text { b. - } \\
\text { c. - } \\
\text { d. - } \\
\text { e. - } \\
\text { f. - }\end{array}$ & $0 \%$ \\
\hline 8 & $\begin{array}{l}\text { Mengoperasikan jaring insang hanyut. Elemen } \\
\text { kompetensi : } \\
\text { a. Melakukan persiapan alat dan perlengkapan } \\
\text { jaring insang hanyut } \\
\text { b. Menurunkan unit jaring insang hanyut } \\
\text { (setting) } \\
\text { c. Menghanyutkan jaring insang (drifting) } \\
\text { d. Menaikkan jaringkeatas kapal (hauling) } \\
\text { e. Menata Alat }\end{array}$ & $\begin{array}{l}\text { Mengoperasikan jaring } \\
\text { insang hanyut. Elemen } \\
\text { kompetensi : } \\
\text { a. - } \\
\text { b. - } \\
\text { c. - } \\
\text { d. - } \\
\text { e. }-\end{array}$ & $0 \%$ \\
\hline
\end{tabular}




\begin{tabular}{|c|c|c|c|}
\hline No & Standar Kompetensi & $\begin{array}{c}\text { Pemenuhan Standar } \\
\text { Kompetensi oleh } \\
\text { Nelayan }\end{array}$ & $\begin{array}{c}\text { Persentase } \\
(\%)\end{array}$ \\
\hline 9 & $\begin{array}{l}\text { Melakukan penangkapan ikan di laut dengan } \\
\text { menggunakan rawai tuna. Elemen kompetensi : } \\
\text { a. Menentukan haluan dan posisi setting } \\
\text { b. Menentukan kedalaman pancing } \\
\text { c. Melakukan persiapan ikan umpan, alat dan } \\
\text { perlengkapan. } \\
\text { d. Menurunkan rawai tuna (setting) } \\
\text { e. Menghanyutkan rawai tuna (drifting) } \\
\text { f. Menaikkan, mengambil ikan hasil } \\
\text { tangkapan dan menyusun kembali rawai } \\
\text { tuna (hauling) } \\
\text { g. Menata Alat }\end{array}$ & $\begin{array}{l}\text { Melakukan penangkapan } \\
\text { ikan di laut dengan } \\
\text { menggunakan rawai } \\
\text { tuna. Elemen kompetensi } \\
\text { : } \\
\text { a. - } \\
\text { b. - } \\
\text { c. - } \\
\text { d. - } \\
\text { e. - } \\
\text { f. - } \\
\text { g. - }\end{array}$ & $0 \%$ \\
\hline 10 & $\begin{array}{l}\text { Melakukan penangkapan ikan di laut dengan } \\
\text { menggunakan huhate. Elemen kompetensi : } \\
\text { a. Menyiapkan ikan umpan hidup di palka } \\
\text { b. Mencari posisi keberadaan ikan } \\
\text { c. Melakukan pemancingan }\end{array}$ & $\begin{array}{l}\text { Melakukan penangkapan } \\
\text { ikan di laut dengan } \\
\text { menggunakan huhate. } \\
\text { Elemen kompetensi : } \\
\text { a. - } \\
\text { b. - } \\
\text { c. - }\end{array}$ & $0 \%$ \\
\hline 11 & $\begin{array}{l}\text { Melakukan perawatan alat penangkap ikan } \\
\text { berbahan utama webbing. Elemen kompetensi : } \\
\text { a. Melakukan perawatan dan pencegahan } \\
\text { kerusakan alat penangkap ikan } \\
\text { b. Menyiapkan jenis, bahan, peralatan untuk } \\
\text { perawatan alat penangkap ikan } \\
\text { c. Melakukan penyimpanan alat penangkap } \\
\text { ikan }\end{array}$ & $\begin{array}{l}\text { Melakukan perawatan } \\
\text { alat penangkap ikan } \\
\text { berbahan utama } \\
\text { webbing. Elemen } \\
\text { kompetensi : } \\
\text { a. Dipenuhi } \\
\text { b. - } \\
\text { c. Dipenuhi }\end{array}$ & $66,66 \%$ \\
\hline
\end{tabular}




\begin{tabular}{|c|c|c|c|}
\hline No & Standar Kompetensi & $\begin{array}{l}\text { Pemenuhan Standar } \\
\text { Kompetensi oleh } \\
\text { Nelayan }\end{array}$ & $\begin{array}{l}\text { Persentase } \\
\text { (\%) }\end{array}$ \\
\hline 12 & $\begin{array}{l}\text { Melakukan perbaikan alat penangkap ikan } \\
\text { berbahan utama webbing. Elemen kompetensi : } \\
\text { a. Melakukan identifikasi kerusakan alat } \\
\text { penangkap ikan } \\
\text { b. Melakukan bongkar muat alat penangkap } \\
\text { ikan dari dan ke kapal } \\
\text { c. Menyiapkan kebutuhan peralatan dan } \\
\text { bahan perbaikan atau penggantian } \\
\text { kerusakan alat penangkap ikan } \\
\text { d. Melakukan perbaikan dengan cara } \\
\text { mengganti bahan (replacing) komponen } \\
\text { utama webbing alat penangkap ikan ang } \\
\text { rusak } \\
\text { e. Melakukan perbaikan dengan cara } \\
\text { memperbaiki (repairing) sebagian } \\
\text { komponen webbing alat penangkap ikan } \\
\text { yang rusak } \\
\text { f. Melakukan perbaikan dengan cara } \\
\text { pengantian bahan (replacing) seluruh atau } \\
\text { sebagian komponen tali ris atas (float line) } \\
\text { dan ris bawah (sinker line) alat penangkap } \\
\text { ikan yang rusak } \\
\text { gelakukan perbaikan dengan cara } \\
\text { perbaikan (repairing) tali di sebagian } \\
\text { komponen ris atas dan bawah alat } \\
\text { penangkap ikan yang rusak }\end{array}$ & $\begin{array}{l}\text { Melakukan perbaikan } \\
\text { alat penangkap ikan } \\
\text { berbahan utama } \\
\text { webbing. Elemen } \\
\text { kompetensi : } \\
\text { a. Dipenuhi } \\
\text { b. - } \\
\text { c. Dipenuhi } \\
\text { d. Dipenuhi } \\
\text { e. Dipenuhi } \\
\text { f. Dipenuhi } \\
\text { g. Dipenuhi }\end{array}$ & $85,71 \%$ \\
\hline 13 & $\begin{array}{l}\text { Melakukan perawatan alat penangkap ikan } \\
\text { berbahan utama tali dan pancing di darat. } \\
\text { Elemen kompetensi : } \\
\text { a. Mengidentifikasi jenis perawatan dan } \\
\text { pencegahan kerusakan alat penangkap ikan } \\
\text { b. Menyiapkan tempat penyimpanan, jenis, } \\
\text { bahan dan jumlah peralatan perawatan dan } \\
\text { pencegah kerusakan alat penangkap ikan } \\
\text { berbahan utama tali dan pancing } \\
\text { c. Melakukan perawatan dan pencegahan } \\
\text { kerusakan alat penangkap ikan }\end{array}$ & $\begin{array}{l}\text { Melakukan perawatan } \\
\text { alat penangkap ikan } \\
\text { berbahan utama tali dan } \\
\text { pancing di darat. Elemen } \\
\text { kompetensi : } \\
\text { a. - } \\
\text { b. Dipenuhi } \\
\text { c. - }\end{array}$ & $33,33 \%$ \\
\hline
\end{tabular}




\begin{tabular}{|c|c|c|c|}
\hline No & Standar Kompetensi & $\begin{array}{c}\text { Pemenuhan Standar } \\
\text { Kompetensi oleh } \\
\text { Nelayan }\end{array}$ & $\begin{array}{c}\text { Persentase } \\
(\%)\end{array}$ \\
\hline 14 & $\begin{array}{l}\text { Melakukan perawatan alat penangkap ikan } \\
\text { berbahan utama tali dan pancing di kapal. } \\
\text { Elemen kompetensi : } \\
\text { a. Mengidentifikasi jenis perawatan dan } \\
\text { pencegahan kerusakan alat penangkap ikan } \\
\text { berbahan utama tali dan pancing yang } \\
\text { diakibatkan oleh pengaruh langsung sinar } \\
\text { matahari, produk minyak, produk kimia, } \\
\text { korosi, hewan pengerat, serangga, } \\
\text { pencurian proses operasi dan konstruksi } \\
\text { kapal } \\
\text { benyiapkan jenis, bahan dan jumlah } \\
\text { peralatan perawatan dan pencegah } \\
\text { kerusakan alat penangkap ikan berbahan } \\
\text { utama tali dan pancing di kapal } \\
\text { Melakukan perawatan dan pencegahan } \\
\text { kerusakan alat penangkap ikan di kapal }\end{array}$ & $\begin{array}{l}\text { Melakukan perawatan } \\
\text { alat penangkap ikan } \\
\text { berbahan utama tali dan } \\
\text { pancing di kapal. Elemen } \\
\text { kompetensi : } \\
\text { a. - } \\
\text { b. Dipenuhi } \\
\text { c. - }\end{array}$ & $33,33 \%$ \\
\hline 15 & $\begin{array}{l}\text { Melakukan perbaikan alat penangkap ikan } \\
\text { berbahan utama tali dan pancing. Elemen } \\
\text { kompetensi : } \\
\text { a. Menghindarkan kerusakan yang } \\
\text { diakibatkan oleh sinar matahari langsung, } \\
\text { minyak, zat kimia berbahaya dan hewan } \\
\text { pengerat } \\
\text { b. Memperbaiki tali temali yang rusak } \\
\text { c. Mengganti komponen alat lainnya yang } \\
\text { rusak } \\
\text { d. Memberikan zat pengawet dan pewarna } \\
\text { pada tali temali }\end{array}$ & $\begin{array}{l}\text { Melakukan perbaikan } \\
\text { alat penangkap ikan } \\
\text { berbahan utama tali dan } \\
\text { pancing.Elemen } \\
\text { kompetensi : } \\
\text { a. - } \\
\text { b. Dipenuhi } \\
\text { c. Dipenuhi } \\
\text { d. - }\end{array}$ & $50 \%$ \\
\hline 16 & $\begin{array}{l}\text { Melakukan penanganan ikan tuna di kapal. } \\
\text { Elemen kompetensi : } \\
\text { a. Menyiapkan peralatan dan tempat } \\
\text { penanganan ikan tuna hasil tangkapan di } \\
\text { kapal } \\
\text { b. Menyiapkan sistem penyimpanan } \\
\text { c. Menangani ikan tuna }\end{array}$ & $\begin{array}{l}\text { Melakukan penanganan } \\
\text { ikan tuna di kapal. } \\
\text { Elemen kompetensi : } \\
\text { a. - } \\
\text { b. - } \\
\text { c. - }\end{array}$ & $0 \%$ \\
\hline 17 & $\begin{array}{l}\text { Melakukan penanganan ikan pelagis kecil di } \\
\text { kapal. Elemen kompetensi : } \\
\text { a. Menyiapkan peralatan dan tempat } \\
\text { penanganan ikan pelagis kecil hasil } \\
\text { tangkapan di kapal } \\
\text { b. Menyiapkan palka penyimpanan } \\
\text { c. Menangani ikan pelagis kecil }\end{array}$ & $\begin{array}{l}\text { Melakukan penanganan } \\
\text { ikan pelagis kecil di } \\
\text { kapal. Elemen } \\
\text { kompetensi : } \\
\text { a. - } \\
\text { b. Dipenuhi } \\
\text { c. Dipenuhi }\end{array}$ & $66,66 \%$ \\
\hline
\end{tabular}




\begin{tabular}{|c|c|c|c|}
\hline No & Standar Kompetensi & $\begin{array}{c}\text { Pemenuhan Standar } \\
\text { Kompetensi oleh } \\
\text { Nelayan }\end{array}$ & $\begin{array}{c}\text { Persentase } \\
\text { (\%) }\end{array}$ \\
\hline 18 & $\begin{array}{l}\text { Melakukan penanganan ikan demersal di kapal. } \\
\text { Elemen kompetensi : } \\
\text { a. Menyiapkan peralatan penanganan ikan } \\
\text { demersal hasil tangkapan di atas kapal } \\
\text { b. Menyiapkan palka penyimpanan } \\
\text { c. Membuang sumber-sumber pembusukan } \\
\text { ikan demersal } \\
\text { d. Melakukan proses pengesan ikan demersal } \\
\text { e. Melakukan proses pembekuan ikan } \\
\quad \text { demersal }\end{array}$ & $\begin{array}{l}\text { Melakukan penanganan } \\
\text { ikan demersal di kapal. } \\
\text { Elemen kompetensi : } \\
\text { a. - } \\
\text { b. Dipenuhi } \\
\text { c. - } \\
\text { d. Dipenuhi } \\
\text { e. - }\end{array}$ & $40 \%$ \\
\hline 19 & $\begin{array}{l}\text { Melakukan penanganan udang di kapal. Elemen } \\
\text { kompetensi : } \\
\text { a. Menyiapkan peralatan dan tempat } \\
\text { penanganan udang hasil tangkapan di } \\
\text { kapal } \\
\text { b. Menyiapkan palka penyimpanan } \\
\text { c. Menangani udang }\end{array}$ & $\begin{array}{l}\text { Melakukan penanganan } \\
\text { udang di kapal. Elemen } \\
\text { kompetensi : } \\
\text { a. - } \\
\text { b. Dipenuhi } \\
\text { c. Dipenuhi }\end{array}$ & $66,66 \%$ \\
\hline 20 & $\begin{array}{l}\text { Merakit alat tangkap pukat hela. Elemen } \\
\text { kompetensi : } \\
\text { a. Menjabarkan desain alat tangkap } \\
\text { b. Menyiapkan kebutuhan peralatan dan } \\
\text { bahan } \\
\text { c. Merangkai komponen alat tangkap }\end{array}$ & $\begin{array}{l}\text { Merakit alat tangkap } \\
\text { pukat hela. Elemen } \\
\text { kompetensi : } \\
\text { a. Dipenuhi } \\
\text { b. Dipenuhi } \\
\text { c. Dipenuhi }\end{array}$ & $100 \%$ \\
\hline 21 & $\begin{array}{l}\text { Merakit alat tangkap jaring insang. Elemen } \\
\text { kompetensi : } \\
\text { a. Menjabarkan desain alat tangkap } \\
\text { b. Menyiapkan kebutuhan peralatan dan } \\
\text { bahan } \\
\text { c. Merangkai komponen alat tangkap }\end{array}$ & $\begin{array}{l}\text { Merakit alat } \\
\text { tangkapjaring insang. } \\
\text { Elemen kompetensi : } \\
\text { a. Dipenuhi } \\
\text { b. Dipenuhi } \\
\text { c. Dipenuhi }\end{array}$ & $100 \%$ \\
\hline 22 & $\begin{array}{l}\text { Merakit alat tangkap rawai tuna. Elemen } \\
\text { kompetensi : } \\
\text { a. Menjabarkan desain alat tangkap } \\
\text { b. Menyiapkan kebutuhan peralatan dan } \\
\text { bahan } \\
\text { c. Merangkai komponen alat tangkap }\end{array}$ & $\begin{array}{l}\text { Merakit alat tangkap } \\
\text { rawai tuna. Elemen } \\
\text { kompetensi : } \\
\text { a. - } \\
\text { b. - } \\
\text { c. - }\end{array}$ & $0 \%$ \\
\hline 23 & $\begin{array}{l}\text { Merakit alat tangkap huhate. Elemen } \\
\text { kompetensi : } \\
\text { a. Menjabarkan desain alat tangkap } \\
\text { b. Menyiapkan kebutuhan peralatan dan } \\
\text { bahan } \\
\text { c. Merangkai komponen alat tangkap }\end{array}$ & $\begin{array}{l}\text { Merakit alat } \\
\text { tangkaphuhate. Elemen } \\
\text { kompetensi : } \\
\text { a. - } \\
\text { b. - } \\
\text { c. - }\end{array}$ & $0 \%$ \\
\hline \multicolumn{3}{|c|}{ Rata-rata pemenuhan standar kompetensi (\%) } & $35,73 \%$ \\
\hline
\end{tabular}


Berdasarkan data pada tabel di atas, didapatkan hasil bahwa nelayan di PPN Karangantu, Banten hanya menguasai 35,73\% dari elemen kompetensi yang seharusnya dimiliki oleh nelayan, sedangkan 64,27\% elemen kompetensi yang lainnya nelayan belum menguasainya. Adapun faktor penyebab minimnya pemahaman nelayan di PPN Karangantu, Banten terkait dengan standar kompetensi yang seharusnya dimiliki oleh nelayan, antara lain rendahnya tingkat pendidikan yang dimiliki oleh nelayan, minimnya kesadaran nelayan akan pentingnya kompetensi, serta belum adanya bentuk sosialisasi maupun pelatihan terkait dengan standar kompetensi nelayan yang diadakan di lokasi tersebut. Selain itu juga, dari 23 jenis kompetensi yang telah ditetapkan, hanya terdapat 7 jenis kompetensi yang dikuasai oleh nelayan di PPN Karangantu, yaitu :

1. Merencanakan operasi penangkapan ikan

Nelayan di PPN Karangantu sebelum melaut, mengakui telah melakukan perencanaan operasi penangkapan ikan. Namun nelayan tersebut hanya menguasai 50\% dari elemen kompetensi yang seharusnya dikuasai. Adapun hal yang dilakukan oleh nelayan terkait merencanakan operasi penangkapan ikan, yaitu mempersiapkan perbekalan maupun logistik yang dibutuhkan pada saat operasi penangkapan ikan, menentukan lokasi atau daerah penangkapan ikan, mempersiapkan alat tangkap yang akan digunakan, serta menentukan jenis ikan sasaran.

\section{Menyiapkan kelaiklautan kapal}

Nelayan di PPN Karangantu menguasai 33,33\% dari elemen kompetensi yang seharusnya dimiliki oleh nelayan terkait menyiapkan kelaiklautan kapal. Adapun hal yang dilakukan oleh nelayan dalam menyiapkan kelaiklautan kapal, yaitu menyiapkan dokumen-dokumen, serta melakukan perekrutan awak kapal. Dokumen-dokumen yang dimaksudkan yaitu dokumen kepemilikan kapal, dokumen izin usaha penangkapan ikan, serta dokumen izin melaut. Fakta menarik yang ditemukan ketika di lapang terkait dengan melakukan perekrutan awak kapal, nelayan setempat biasanya mengajak teman ataupun kerabatnya yang sedang tidak bekerja untuk melengkapi jumlah awak pada saat melakukan operasi penangkapan.

\section{Melaksanakan tugas jaga laut}

Nelayan di PPN Karangantu menguasai 50\% dari elemen kompetensi yang seharusnya dimiliki oleh nelayan terkait melaksanakan tugas jaga laut. Adapun hal yang dilakukan oleh nelayan terkait dengan melaksanakan tugas jaga laut, yaitu melakukan pemantauan rute pelayaran pada saat operasi penangkapan ikan, melakukan pemantauan terhadap alur pelayaran, menentukan arah melaut, dan melihat-lihat sekitar lokasi pada saat operasi penangkapan. Dalam hal melaksanakan tugas jaga laut, biasanya dilakukan oleh nahkoda ataupun juga kapten kapal.

\section{Merakit alat penangkap ikan}

Nelayan di PPN Karangantu mengakui bahwa sepenuhnya dapat merakit alat tangkap sendiri. Pada proses dilakukan wawancara terhadap nelayan, didapatkan 5 jenis alat penangkap ikan yang mendominasi biasa digunakan oleh nelayan, yaitu (1) jaring insang cara yang dilakukan oleh nelayan dalam merakit alat tersebut yaitu, membuat desain, menyediakan alat dan bahan yang dibutuhkan berupa benang, coban, pelampung, pemberat, dan juga tali, kemudian menjurai benang tersebut dan merakit komponen sehingga menjadi alat tangkap berupa jaring insang, (2) bubu cara yang dilakukan oleh nelayan dalam merakit bubu, yaitu membuat desain, menyiapkan alat dan bahan berupa jaring $\mathrm{PE}$, serta besi untuk membuat kerangka bubu, kemudian merangkai komponen tersebut dengan cara menyulam jaring PE ke dalam kerangka bubu, (3) dogol dan (4) payang cara yang dilakukan oleh nelayan dalam merakit alat tersebut yaitu menyiapkan alat dan bahan yang dibutuhkan berupa jaring, pelampung, pemberat, dan juga tali, kemudian merangkai komponen tersebut menjadi alat tangkap berupa payang dan dogol, serta 5) pancing cara yang dilakukan oleh nelayan dalam merakit alat tersebut, yaitu menyiapkan alat dan bahan berupa benang pancing, pelampung, pemberat, dan kail, kemudian merangkai komponen tersebut menjadi alat tangkap berupa pancing. 


\section{Melakukan perawatan alat penangkapan ikan}

Nelayan di PPN Karangantu mampu melakukan perawatan alat penangkap ikan. Terdapat 3 jenis perawatan yang dilakukan oleh nelayan yaitu melakukan perawatan alat penangkap ikan yang menggunakan bahan webbing, melakukan perawatan alat penangkap ikan berbahan utama tali dan pancing di darat, dan melakukan perawatan alat penangkap ikan berbahan utama tali dan pancing di atas kapal. Ketiga jenis perawatan tersebut, masing-masing nelayan menguasai 66,66\% terkait perawatan alat penangkap ikan berbahan webbing, serta 33,33\% terkait perawatan alat penangkap ikan berbahan utama tali dan pancing di darat dan di atas kapal. Adapun cara yang dilakukan oleh nelayan terkait melakukan perawatan alat penangkap ikan berbahan utama webbing, yaitu dengan cara membersihkan serta menjemur alat tangkap setelah digunakan. Sedangkan cara yang dilakukan nelayan terkait perawatan alat penangkap ikan berbahan utama tali dan pancing, yaitu dengan menyimpan di dalam kotak penyimpanan, serta menggulung alat tersebut setelah digunakan kemudian ditutupi menggunakan terpal.

\section{Melakukan perbaikan alat penangkap ikan}

Nelayan di PPN Karangantu mampu melakukan perbaikan alat penangkap ikan. Terdapat 2 jenis perbaikan alat penangkap ikan, yaitu perbaikan alat penangkap ikan berbahan utama webbing, serta perbaikan alat penangkap ikan berbahan utama tali dan pancing. Kedua jenis perbaikan tersebut, masing-masing nelayan menguasai $85,71 \%$ perbaikan alat penangkap ikan berbahan utama webbing, serta 50\% perbaikan alat penangkap ikan berbahan utama tali dan pancing. Cara yang dilakukan oleh nelayan terkait melakukan perbaikan alat penangkap ikan, yaitu mencari bagian alat tangkap yang rusak, menambal kerusakan pada alat tangkap yang berbahan webbing, sedangkan alat tangkap yang berbahan utama tali dan pancing, mengganti komponen yang rusak.

\section{Melakukan penanganan ikan di atas kapal}

Nelayan di PPN Karangantu saat mendapatkan hasil tangkapan, nelayan tersebut mengakui telah melakukan penanganan ikan di atas kapal. Terdapat 3 jenis ikan yang ditangani oleh nelayan, antara lain ikan pelagis kecil, ikan demersal, dan udang. Ketiga jenis ikan tersebut, terkait dengan penanganan ikan di atas kapal masing-masing nelayan menguasai $66,66 \%$ untuk penanganan ikan pelagis kecil dan udang di atas kapal, serta $40 \%$ untuk penanganan ikan demersal. Adapun cara yang dilakukan oleh nelayan terkait dengan melakukan penanganan ikan di atas kapal, yaitu melepaskan ikan dari jeratan alat tangkap, mensortir ikan berdasarkan jenisnya, menyiapkan tempat penyimpanan ikan hasil tangkapan, serta memberikan es dan garam pada ikan hasil tangkapan tersebut.

Nelayan di PPN Karangantu, dapat dinilai bahwa nelayan tersebut mampu mengerjakan serta mempraktekkannya, akan tetapi walaupun nelayan mampu mengerjakan serta mempraktekannya sebagian besar nelayan tersebut kurang memahami kompetensi yang telah ditetapkan. Selain itu juga, kompetensi yang dimiliki oleh nelayan di PPN Karangantu, masih bisa ditingkatkan lagi, dengan cara memberikan pendidikan maupun pelatihan kepada nelayan. Pendidikan dan pelatihan dapat ditempuh melalui jalur formal maupun informal. Jalur formal dapat ditempuh dengan cara menempuh jenjang pendidikan yang telah dipersiapkan, sedangkan jalur informal dapat ditempuh dengan cara mengikuti bentuk pelatihan yang diselenggarakan oleh lembaga pemerintah yang bergerak pada bidang peningkatan kualitas sumberdaya manusia. Maka dari itu peran pemerintah sangat dibutuhkan dalam meningkatkan kompetensi nelayan. Hal tersebut ditunjukkan agar terciptanya keselamatan kerja bagi nelayan, sehingga dapat meminimalisir terjadinya kecelakaan kapal, khususnya kapal penangkap ikan. 


\section{KESIMPULAN DAN SARAN}

\section{Kesimpulan}

1. Kompetensi yang seharusnya dimiliki oleh nelayan telah diatur dalam Standar Kompetensi Kerja Nasional Indonesia (SKKNI) dalam bidang penangkapan ikan yang diterbitkan oleh Keputusan Menteri Tenaga Kerja dan Transmigrasi No 298 Tahun 2013 Tentang Penetapan Standar Kompetensi Kerja Nasional Indonesia Kategori Pertanian, Kehutanan Dan Perikanan, dimana terdapat 23 unit jenis kompetensi yang seharusnya dimiliki oleh nelayan.

2. Kompetensi yang dimiliki oleh nelayan di PPN Karangantu, Banten terbilang cukup rendah, hal tersebut dikarenakan 35,73\% nelayan tersebut kurang memahami tentang kompetensi kerja yang seharusnya dimiliki oleh nelayan. Selain itu juga,hanya terdapat 7 jenis kompetensi yang dikuasai oleh nelayan di PPN Karangantu, yaitu merencanakan operasi penangkapan ikan, menyiapkan kelaiklautan kapal, melaksanakan tugas jaga laut, merakit alat penangkap ikan, melakukan perawatan alat penangkap ikan, melakukan perbaikan alat penangkapan ikan, serta melakukan penanganan ikan di atas kapal. Minimnya kompetensi yang dimiliki oleh nelayan, dapat berdampak langsung terhadap pengetahuan serta keterampilan yang dimiliki oleh nelayan itu sendiri.

Saran

1. Perlu diadakannya sosialisasi tentang kompetensi yang seharusnya dimiliki oleh nelayan sesuai dengan SKKNI yang telah ditetapkan.

2. Perlu diadakan pelatihan yang dilaksanakan secara berkelanjutan agar kompetensi nelayan dapat terus meningkat.

\section{DAFTAR PUSTAKA}

[FAO] Food and Agriculture Organization. 2000. The State of World Fisheries and Aquaculture.

[ILO] International Labour Organization. 2004. Human Resource Development. No 195

[IMO] International Maritime Organization. 1960. International Convention for the Safety of Life at Sea. London (EN): IMO.

[IMO] International Maritime Organization. 2007. Any Other Business. Outcome of SLF 50.STW 39/11/1. Sub Committee on Standard of Training and Watchkeeping. 39 Th Session. London (EN): IMO.

[Kemenhub] Kementerian Perhubungan. 2005. Peraturan Menteri Perhubungan Nomor: PM 9 Tahun 2005 tentang Pendidikan dan Pelatihan, Ujian serta Sertifikasi Pelaut Kapal Penangkap Ikan. Jakarta (ID): Kemenhub.

[KKP] Kementerian Kelautan dan Perikanan. 2011. Peraturan Menteri Kelautan dan Perikanan Nomor: PM 7 Tahun 2011 tentang Sistem Standar Mutu Pendidikan dan Pelatihan, Ujian, Serta Sertifikasi Pelaut Kapal Penangkapan Ikan. Jakarta (ID): KKP

Departemen Perhubungan. 2000. Pusat pemelitian dan pengembangan perhubungan laut dalam suatu final report penelitian kecelakaan kapal di Indonesia dan upaya mengatasinya. Jakarta (ID): Dephub. 136 hal.

Hamzens WPS., Sumardjo. 2007. Strategi Inovasi Sosial Pengembangan Mutu Sumber Daya Manusia Nelayan. Jurnal Penyuluhan. 3(1): 1-10.

Pemerintah Republik Indonesia. 2003. Undang-Undang Republik Indonesia Nomor 13 Tahun 2003 tentang Pendidikan Nasional. Jakarta (ID): Sekretariat Negara. 
Pemerintah Republik Indonesia. 2003. Undang-Undang Republik Indonesia Nomor 20 Tahun 2003 tentang Ketenagakerjaan. Jakarta (ID): Sekretariat Negara.

Pemerintah Republik Indonesia. 2004. Undang-Undang Republik Indonesia Nomor 31 Tahun 2004 tentang Perikanan. Jakarta (ID): Sekretariat Negara.

Pemerintah Republik Indonesia. 2008. Undang-Undang Republik Indonesia Nomor 17 Tahun 2008 tentang Pelayaran. Jakarta (ID): Sekretariat Negara.

Pemerintah Republik Indonesia. 2009. Undang-Undang Republik Indonesia Nomor 45 Tahun 2009 tentang Perikanan. Jakarta (ID): Sekretariat Negara.

Retnowati H., A.Sukmawati, dan T. W. Nurani. 2014. Strategi Peningkatan Kinerja Nelayan dalam Rantai Pasok Ikan Layur melalui Pengembangan Modal Insani di Pelabuhanratu. Manajemen IKM. 9(2): 140-149.

Subri M. 2005. Ekonomi Kelautan. Jakarta (ID): Raja Grafindo Persada, Jakarta.

Suryabrata S. 1983. Metodologi Penelitian. Jakarta (ID): CV. Rajawali.

Unus Fahriny. 2004. Analisis Kebijakan Mengenai Keselamatan Nelayan Dan Kapal Ikan Di Laut [Skripsi]. Bogor (ID): Institut Pertanian Bogor

Wahyono, A. 2012. Penanganan Ikan Hasil Tangkapan di Atas Kapal. Kementerian Kelautan dan Perikanan Balai Besar Pengembangan Penangkapan Ikan.

Wibowo. 2009. Manajemen Kinerja. Jakarta (ID): Rajawali. 